POLIIICAL ECONOMY RESEARCH INSTITUTE

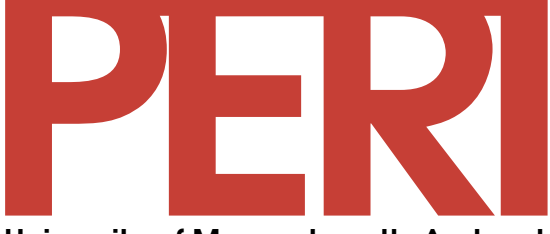

University of Massachusetts Amherst

\title{
Inward Foreign Direct Investment and Inter-Industry Wage Differentials In U.S. Manufacturing Industries
}

\author{
Minsik Choi
}

2003

10th floor Thompson Hall University of Massachusetts Amherst, MA, 01003-7510 Telephone: (413) 545-6355 Facsimile: (413) 545-2921

Email:peri@econs.umass.edu Website:

http://www.umass.edu/peri/

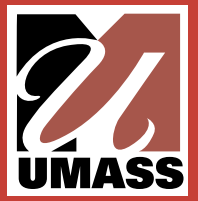


INWARD FOREIGN DIRECT INVESTMENT AND INTER-INDUSTRY WAGE DIFFERENTIALS IN U.S. MANUFACTURING INDUSTRIES

MINSIK CHOI*

Minsik Choi is Assistant Professor of Economics Department at the University of Massachusetts, Boston. The author is grateful to Jerry Epstein for his support and encouragement throughout the whole process of this study, and to Michael Ash, and Stephanie Luce for their comments and suggestions. Of course, I alone am responsible for all errors and omissions.

A data appendix and additional results used to generate the results presented in this paper are available upon request from Minsik Choi at University of Massachusetts Boston, 100 Morrissey Blvd., Boston, MA 02125. 


\begin{abstract}
This study investigates the effects of inward foreign direct investment on local workers' wages by focusing on U.S. manufacturing industries for the period from 1987 to 1992 . I use two different approaches to control individual characteristics and to implement estimation in this study: (1) One-step estimation with industry-state level of inward foreign direct investments, and (2) Two-step industry characteristic regression approach. I find that the higher presence of foreign firms is associated with higher local wages after workers' observable characteristics are controlled for in cross-section analysis. However, I did not find a positive association between inward FDI activities and industry wage premiums within industry in a panel data analysis. In this analysis, inward FDI activities appeared to be negatively associated with worker's industry wage premium for workers with more than high a school education.
\end{abstract}




\section{Introduction}

This study aims to provide additional evidence to the literature on the impact of inward foreign direct investment on local labor markets by investigating at inward foreign direct investment (FDI) in U.S. manufacturing industries. One of the important aspects of the recent globalization process is the increase in FDI stock. The ratio of world FDI stock to world gross domestic product increased from $5 \%$ to $16 \%$ from 1979 to 1999 and world FDI inflows also rose to 14\% (UNCTAD World Investment Report, 2000).

When local governments offer various benefits such as tax exemption and free or low cost land use to attract foreign investment, they hope that FDI inflows will create jobs and increase welfare for workers. This is the case for both local governments of developing countries and of developed countries. In 1999, 67.7\% of total inward stock of FDI was distributed in developed countries while only $32.1 \%$ was distributed in developing countries (UNCTAD World Investment Report, 2000). In the United States, the value of inward foreign direct investment was merely one quarter of U.S. direct investment abroad in the late 1970s, but it had reached over three quarters of the level of U.S. direct investment abroad by 1997-99 (Lipsey, 2001).

Previous studies on the effect of inward FDI on labor market outcomes have shown that foreign firms are more productive and pay higher wages compared to 
domestic firms (Lipsey, 1994, Doms and Jensen, 1996, Feliciano and Lipsey, 2001). These studies have also noted that the increased presence of foreign manufacturing plants is associated with increases in real wages for all workers in that industry and local area. In other words, there exists a positive spillover-effect of foreign investment on the local labor market (Figlio and Blonigen, 2000, Lipsey and Sjöholm, 2001).

However, using the US manufacturing level data from 1977 to 1994, Blonigen and Slaughter (1999) conclude that inward FDI has not contributed to U.S. within-industry skill upgrading. In fact, they found that greater Japanese Greenfield (new investment) affiliate's presence is significantly associated with lower relative demand for skilled workers. In high skill intensive industries, there is no evidence that foreign-owned establishments pay wages that are different from those paid by domestic-owned establishments (Feliciano and Robert Lipsey (2001)). Furthermore, Hanson (2001) found some evidence that a host country's subsidies to foreign firms might actually lower its welfare.

As these contradictory findings on the effect of inward foreign direct investment on local labor markets suggest, there are several different mechanisms by which foreign investments might affect local wages. Hence they cannot be predetermined. Even if we assume that foreign firms pay higher wages than do domestic firms as several studies have found, their impact on local labor markets cannot be clearly predicted. This is primarily because the impact depends upon 
whether foreign investments are carried out through new investment (Greenfield investment) or through mergers and acquisitions of local firms. This impact also depends on the relative demand for skilled/less skilled workers of foreign owned firms.

For instance, let's suppose that a foreign firm is established in a local area in which there are domestically owned firms that produce the same product as the new foreign firm and that the latter uses the same skill structure of its workers as domestic ones. This would suggest that the demand for skilled and less skilled workers in the local area will increase, positively impacting the wages for both. However, if a newly established foreign firm uses more skilled workers than the local firms use, then only the wages for skilled workers will increase. Table 1 summarizes the possible directions of local wage changes in the presence of foreign ownership. If foreign investments are carried out through the merger and acquisition of local firms, their impact on local wages is not clear for both skilled and less-skilled workers. Further, if the newly acquired firm uses the same management style that has practiced before changes in ownership structure, no significant changes in local wages will result immediately for both skilled and less-skilled workers. However, if foreign ownership tries a different management style, then local wages will also change accordingly. In the United States, approximately $95 \%$ of employment in new foreign direct investments have taken place in the form of acquisitions of existing local firms 
between 1987 and 1992 (Feliciano and Lipsey, 1999). Therefore, their impact on U.S. labor market cannot be predetermined clearly as described above.

In this study, I investigate the effects of inward foreign direct investment on local workers' wages by focusing on U.S. manufacturing industries for the period from 1987 to 1992 using individual level data. Previous studies that used the plant level data (or industry level) on wages could not control for variation of individual characteristics including occupational differences within workplaces and industries. Two different approaches are used to control individual characteristics and to implement estimation in this study: (1) One-step estimation with industry-state level of inward foreign direct investments, and (2) Two-step industry characteristic regression approach.

The ideal data for this study would be individual level data that has information both on the ownership structure of firm and on the level of foreign ownership presence in local labor markets. Since no data exist for this purpose, I use grouping technique in micro data by using both Current Population Survey (CPS) Merged Outgoing Groups and Bureau of Economic Analysis (BEA) Foreign Direct Investment in the U.S. Establishment data. Industry-state level cell is created for inward foreign direct investment levels in the first approach. I estimate inter-industry wage differentials and regress them on industry characteristics in the second approach. 
To preview the results, I found that the fraction of foreign firms in the industry and the state is associated with higher wages after workers' observable characteristics are controlled for in cross section analysis. However, I did not find a positive association between inward FDI activities and industry wage premia within industry with a panel data analysis. In this analysis, inward FDI activities appeared to be negatively associated with worker's industry wage premium for workers with more than high a school education. This finding suggests that inward foreign direct investment has not contributed to the improvement of worker's welfare for the period from 1987 to 1992.

The remainder of the paper is organized as follows. The next section discusses the methodology and data utilized in this study. Section three presents the econometric findings regarding the impact of inward FDI upon local worker's wages and discusses various interpretations of empirical evidences. The final section provides an overall assessment of this study and relates the findings here with the literature at large.

\section{Methodology and Data}

Previous econometric studies on the relationship between inward foreign direct investment and workers' wages have used firm average wages or industry average wages, and therefore did not control for workers' heterogeneity within the 
firm or industry. ${ }^{1}$ If foreign firms hire better-qualified workers and pay higher wages than do locally owned firms, the firm level or industry level analysis with average level of wages cannot capture this fact. In other words, econometric results suffer from selection bias.

Unfortunately, no individual data with detailed ownership of workplace are available with which one can control for workers' characteristics in investigating the effect of foreign ownership on wages. This makes an individual level analysis in addressing the question foreign ownership's effect on local wages difficult. However, one can pursue this type of analysis by merging two different sources of data. I adopted two different strategies to control workers' characteristics and make use of available datasets for this purpose: (1) OLS estimation of the earning equations by including industry-state level characteristics, and (2) Inter-industry wage differential approach: two-stage estimation approach (e.g. Dickens and Katz, 1987; Krueger and Summers, 1988).

2.1 One-step estimation with industry-state level of FDI

The first approach is to include the proportion of the foreign firms at stateindustry level in the earnings equation by using Current Population Survey (CPS)

\footnotetext{
${ }^{1}$ Some studies distinguished production workers' wages from non-production workers. For example Blonigen and Salughter (2001).
} 
data. I constructed the share of foreign firms at the level of industry and regional (50 States) cells by using Foreign Direct Investment in the United States Establishment Data for 1992. This data is available as the result of the project that links Bureau of Economic Analysis (BEA) enterprise, or company, data on foreign direct investment in the United States with the Census Bureau's establishment data for all U.S. companies. $^{2}$

I use 1991 to 1993 Merged Outgoing Rotation Groups from the CPS to construct cells at the industry-state level. I used 63 three-digit manufacturing industries (some industries include more than two three digit industry codes - a complete list of the industry is given in the appendix), and 50 States (District of Columbia is merged with Maryland and there are only 20 manufacturing firms in DC). The estimation is restricted to workers aged 16-76 who satisfy sample-selection rules: (1) the individual is employed in the private sector; (2) the individual works for pay more than one hour a week; (3) the individual earns more than a dollar and less than 250 dollars an hour; (4) the individual is employed in a manufacturing sector except tobacco industry.

In order to assess the effect of foreign ownership on the local wages, I estimated the following regression form,

\footnotetext{
${ }^{2}$ FDI data in the United States are not adjusted for percentage of foreign ownership. As long as one establishment of each U.S. affiliate that are owned by foreign investor by more than $10 \%$ will be included as foreign-owned establishment. Most U.S. affiliates are majority owned (that is, affiliates that are owned more than 50 percent by foreign direct investors) accounted for 83 percent of all employment by U.S. affiliates in 1992 (Bureau of Economic Analysis, Foreign Direct Investment in the United States Establishment Data for 1992)
} 


$$
\ln w_{i j s}=X_{i j s} \beta+\gamma D_{j s}+\varepsilon_{i j s}
$$

$w_{i j s}$ is the logarithm of the hourly wage of individual $i$ in industry $j$ and state $s . X_{i j s}$ $(1 k)$ is a vector of demographic characteristics, which includes years of schooling, experience, and its square, dummies for female, non-white, whether the individual lives in an SMSA, and part-time status. $D_{j s}$ is the fraction of firms that are owned by foreign entity in each industry-state cell, which does not vary at the individual level. $\varepsilon_{i j s}$ is the usual i.i.d., zero-mean regression error with constant variance. $\beta$ and $\gamma\left(\begin{array}{ll}k & 1\end{array}\right)$ are parameters to be estimated.

Since I use the aggregated industry-state level data at individual micro data analysis, the associated econometric issue should be addressed. When the aggregation data are used at micro data analysis, it is likely to bias the estimates, which leads to incorrect standard errors that exaggerate the statistical significance of the included group variables (Moulton, 1986). In order to implement the estimation of equation (1) and to obtain standard errors that are robust to a group structure in error term, I included group-level, which is an industry-state cell clustering in the estimation.

\subsection{Two-stage Regression Approach}


I also employ a two-step estimation method in order to examine the effects of inward foreign direct investment activity on inter-industry wage differentials in US manufacturing sector. This study on industry wage differentials is based on the assumption that industry wage differentials depend on industry characteristics. The extension sought in this study is that inward foreign direct investment activity also affects industry wage differentials as important industry characteristics. I estimated the effect of inward FDI on wages by including industry fixed effects in the regression analysis to control for industry-specific characteristics.

The wide wage differences across industries have been persistent for a long period of time (Kruger and Summers, 1987) and this fact has challenged standard competitive labor market theories (Katz and Summers, 1989; Borjas and Ramey, 2000). The industry wage premium is the component of the wage that is given to individuals while working in the industry, but is not due to any specific individual characteristics, either observed or unobserved. ${ }^{3}$ In this study, industry premia are treated as compensation for particular industry characteristics to see whether the presence of foreign ownership in the industry is associated with industry wage premia.

\footnotetext{
${ }^{3}$ This premium may capture the fact that the industry of affiliation is important in determining wages, as in the case of compensating differentials (loyalty, firm-specific knowledge, or (dis)comfort), or it may be that industry affiliation is systematically correlated with unobserved worker attributes (as would result from a worker sorting process based on unobserved ability), or both (Gibbons and Katz, 1992).
} 
There are two advantages in using this two-step approach over a one-step approach in this study. First, there are more detailed data on inward foreign direct investment that can be utilized with the two-step approach. In order to avoid disclosure of data on individual companies, BEA does not report information on employment and output information on industry-state level. For this reason, I am only able to use information of number on foreign firms in industry-state level in the previous one-step approach. However, I can utilize information about employment and output share of foreign firms in industry level with the two-stage approach because higher aggregation allows BEA to report data without the possibility of revealing information about individual firms. In addition, with the two-step approach, I can utilize longer period data on inward FDI to examine dynamics within industry. A possible drawback of cross-section data analysis in the previous section is that it cannot be used to control for industry fixed effects that may be correlated with the regressors. The existence of such correlations can lead to biased estimates. In order to correct this problem and utilize more detailed data, I used industry fixed effect estimation in the second stage of the two-step regression approach. I used three different measures of inward FDI activity in US manufacturing industries in the fixed effect estimation: (1) the proportion of number of foreign-owned establishments in US manufacturing industries, (2) the proportion of employee hired by foreign-owned establishments in US manufacturing industries, and (3) the proportion of output produced by foreign-owned establishments in US manufacturing industries. While 
the first measure is available only for two years, 1987 and 1992, the remaining two measures are available for six years from 1987 to 1992.

A unique industry level panel data set is constructed here by using three different data sets: (1) the Merged Outgoing Rotation Group (MORG) of Current Population Survey (CPS) data, (2) U.S. Direct Investment in the United States (FDIUS), Establishment Data for Manufacturing collected by Bureau of Economic Analysis (BEA) from survey, and (3) the National Bureau of Economic Research (NBER)'s Manufacturing Productivity Database. The 63 BEA industry categories in manufacturing sector are used. Details about industry categories used in this study are provided in Appendix C.

$$
\begin{aligned}
& \ln w_{i j}=X_{i j} \beta+D_{i j} w_{j}^{*}+\varepsilon_{i j} \text { (stage 1) } \\
& w_{j t}^{*}=\alpha+\beta_{p} P_{j t}+\beta_{f} F_{j t}+\eta_{j t}(\text { stage } 2)
\end{aligned}
$$

where $D_{i j}$ is a dummy for industry $j, w_{j}^{*}$ is the wage premium in industry $j$, and $P_{j t}$ is the vector of control variables for industry characteristics: unionization, profit level, capital-labor ratio, and average establishment size, $F_{j t}$ is the inward foreign direct investment in the industry $j$ measured either by the foreign establishments' 
employment share or sales share of U.S. industry-wide activity, and $t$ indexes time. ${ }^{4}$

In the first stage, logarithms of individual wages are regressed on individual characteristics and $J$ industry dummies with coefficients $w_{j}^{*}$. In the second stage, $w_{j}^{*}$ are regressed on industry characteristics. ${ }^{5}$ The disturbances in the second-step regression equations are heteroskedastic because the data for dependent variable themselves are estimated coefficients of the first-step regressions. I used the estimation with weights proportional to the covariance matrix of the estimated wage differentials from the first-stage regressions.

\section{Empirical findings and Discussion}

3.1 Results from one-step estimation with industry-state level of FDI

The results from the estimation of equation (1) are shown in Table 5. Coefficients of the individual characteristics show signs and magnitudes that are very similar to those found in many studies. Inclusion of the industry-state level foreign firm's presence in the regression is the extension made in this study. The sign of the

\footnotetext{
${ }^{4} X_{i j}$ are same vector used in regression equation (1).

${ }^{5}$ Inter-industry wage differential are normalized so that one can compare estimated industry wage premiums with average worker instead of workers in omitted industry. See Krueger and Summers (1988) for details.
} 
estimated coefficient is positive and it is statistically significant. This suggests that the fraction of foreign firms in the industry and region is associated with higher pay for workers after workers' observable characteristics are controlled. This finding is consistent with findings from previous studies that foreign firms pay higher wages to their workers with industry level analysis. The magnitude of coefficient of the fraction of foreign firms is very small, however, and implies that a $10 \%$ increase in foreign firms fraction leads to $0.02 \%$ increase in wages.

In tables 6 , results from the regression equation with industry and state dummies are shown in columns (2)-(4). Including these dummies reduces the size of coefficients and their statistical significance. When industry and state dummies are added together, the estimated coefficient of the fraction of foreign firms is close to zero and statistically insignificant. Notice that including industry dummies in regression reduced estimated coefficient of FDI variable to 0.0004 and therefore reduced the $t$-statistic. Furthermore, when industry and region (state) dummies are added together into the regression equation, the estimated coefficient becomes even smaller and the null hypothesis of no explanation power of foreign ownership on individual wages cannot be rejected. However, it should be noted that the sizes of some industry-state cells are very small.

Howenstein and Zeile (1994) found wage differential between foreign owned firms and domestically owned firms and they attributed the wage differential to the larger average size of the foreign firms by using U.S. manufacturing industry data 
with detailed information on industry and location. Feliciano and Lipsey (1999) also found that the wage differential between foreign owned and domestically owned establishments disappears once controls such as average size of establishment, and unionization are added by using establishment level data. Table 2 shows that the foreign direct investments are heavily concentrated in industries that are capital intensive. The top five industries in terms of foreign ownership presence are Chemicals and allied products (SIC code 28), Petroleum and coal products (SIC code 29), Stone, clay, and glass products (SIC code 32), Primary metal industries (SIC code 33), and Electronic and other electrical equipment (SIC code 36). Table 3 also reveals that foreign-owned establishments are densely located in Southern States. Almost every Southern State has inward FDI activity more than nation-wide average in every measure.

\subsection{Results from the two-stage approach}

Results from the second-stage regressions of two-stage estimation method are shown in table 4.7. Column (1) and (2) in all panels show results from the industry fixed effect regression of industry wage differentials on two different measures of inward foreign direct investment with other industry characteristics. Foreign affiliates' employment share is measured by the fraction of foreign owned establishments' employees in all U.S. establishments' employees. Foreign affiliate 
shipment is measured by the fraction of foreign owned establishments' shipments or sales in all U.S. establishments' shipments or sales. Column (3) and (4) in all panels show results from the industry fixed effect regression of industry wage differentials on inward FDI variables without other control regressors. From all workers panel, it is shown that two measures of inward foreign direct investments activity are negatively associated with inter-industry wage differentials and they are statistically significant at $5 \%$ level except for the first column. This negative sign implies that workers wage premia due to their industry affiliation decreases as inward foreign direct investment activity increases. The estimated coefficient ranges from -0.08 to 0.13 depending on measure and specification, which implies that the pay for all workers is about 1 percent lower for any 10 point changes in foreign firms employment.

I also estimated the second-stage regression with different groups in terms of workers' educational attainment to see if inward FDI has different effects on wages across different skilled groups. The results are shown in the second and the third panels in table 6. Even though the null hypothesis of zero effect of inward FDI on wages cannot be rejected, the signs of coefficients in workers with up to high school education are uniformly negative. However, the negative effect of inward FDI activity becomes substantial and statistically significant in the case of skilled workers. The estimated coefficients are around -0.20 implying that pay for workers with more than high school education decreases by $2 \%$ at any 10 points increase in inward 
foreign direct investment activity. Blonigen and Slaughter (2001) found no evidence that inward FDI activity contributed to skill upgrading in U.S. manufacturing industries by using industry level analysis and the result from the second-stage regression of this study support their findings. Additional regression of inter-industry wage differentials among union members on inward FDI activity fails to show statistical significance.

The contrast between results from the industry characteristics approach and results from the individual level analysis seems puzzling at first. However, this contradiction can be accounted for by differences between these two approaches. While the first approach is a cross sectional approach, the second approach used panel data analysis to control for industry fixed effects that may be correlated with other regressors. With fixed effects panel analysis, results from the two-stage approach reveal that biases in the cross-section approach in this study introduced by omitting fixed effects are substantial. Since the measures of inward FDI activity are different in two methods, results may not be completely comparable and the contrasting results are due differences in measures rather than omitted industry fixed effects. In order to check this possibility, I regressed equation (4-3) with inward FDI variable measured by the proportion of number of foreign-owned establishment for only two years (1987 and 1992) due to the availability of data. While there are still discrepancy between two-year period and six-year period (the other two-stage estimations), the results in table 8 show that there is no statistically significant 
relationship between industry wage differentials and inward FDI activity measured by the proportion of the number of foreign-owned establishments in US manufacturing sectors, which supports the bias problem that resulted from omitted industry fixed effects in the cross-section approach. ${ }^{6}$

The negative association of inward foreign direct investment activities with industry wage premiums, especially for skilled workers, might suggest an increase in competition within an industry between foreign owned and domestically owned firms. Inter-industry wage differential captures the portion of rents that are given to workers. It is possible for inter-industry wage differential to decrease as the whole size of rent shrinks, which results from more competition within an industry. Therefore, even though the presence of individual foreign establishment is associated with higher pay for individual workers, overall industry wage premium that workers used to enjoy can be negatively associated with higher foreign firms' activity within an industry, as the second-step regression results demonstrate.

It is also possible that more foreign firms within an industry are associated with a weaker bargaining position of skilled workers. Approximately $95 \%$ of employment in new foreign direct investments was in acquired enterprises between 1987 and 1992 (Feliciano and Lipsey, 1999). Growing activity of foreign firms within industry could imply that domestic ownership has been simply converted to

\footnotetext{
${ }^{6}$ When I estimated regression equation (3) with the other two inward FDI variables by treating panel data as a cross section data, the results become similar to those from the first approach. The estimated coefficients of inward FDI activities are around 0.50 and they are statistically significant at $5 \%$ level $(t$-statistics are around 10).
} 
foreign ownership. Under new management workers might feel more insecure about their job than under domestic ownership, for it is well known that the most important reason for the opposition of foreign ownership is the fear of job losses.

\section{Conclusion}

This paper explores the relationship between inward foreign direct investment and wages in U.S. manufacturing industries. If inward FDI takes place mostly by acquisition of existing domestically owned firms, the demand shift effects might not be large enough to influence wages in local labor market. Instead, even though foreign-owned firms tend to pay higher wages, it is not clear that workers benefit from new ownership structure and new management policy. It is also possible that increasing inward FDI activities within an industry can change a rent sharing system that would be persistent under local ownership by increasing competition among firms within industry.

Results from this study support this idea. This study demonstrated that the fraction of foreign firms in an industry and state is associated with higher pay for workers after workers observable characteristics are controlled in a cross section analysis. However, it did not find a positive association between inward FDI activities and industry wage premia within an industry with a panel data analysis. Instead, inward FDI activities appeared to be negatively associated with worker's 
industry wage premium among workers with more than a high school education. This finding suggests that inward foreign direct investment has not contributed to improve workers welfare for the period from 1987 to 1992.

This study extends the existing literature on effects of inward FDI in terms of two aspects. First, this study used individual level analysis in order to control workers characteristics in finding effects of inward FDI on wages. Previous empirical analysis in this field could not control workers characteristics since they used average firm or industry level wages. Second, this study also used a unique panel data set to understand dynamics of relationship between inward FDI activities and wages within industry. While previous studies that used industry-level panel data set could not control worker's characteristics, this study used two-stage estimation method to do so in analyzing effects of inward FDI on wages.

Results from this study suggest further studies are necessary to examine the impact of the growing presence of foreign ownership on the bargaining relationship between foreign owners and local workers and their spillover effects on domestically owned firms. Threat effects theory suggests that the threat by firms to move production abroad, or the threat to outsource may have an important impact on wages and profits even in the absence of large price or quantity changes due to changes in the environment of capital mobility, such as the establishment of NAFTA and WTO (Crotty, Epstein and Kelly, 1998, Rodrik, 1997;1999, Reddy 2000). If foreign investors use the threat to move or close plants in bargaining situations, labor unions 
might perceive it as a more credible threat than domestic firms. Therefore it is very important to look at the bargaining relationship between foreign owners and local workers (union) to understand effects of inward FDI activities on wages in local labor market theoretically and empirically. 
References

Borjas, George J. and Valerie A. Ramey, 2000, "Market Responses to Interindustry Wage Differentials, NBER Working Paper 7799, NBER.

Feliciano, Zadia and Robert E. Lipsey, 1999, "Foreign Ownership and Wages in the United States, 1987-1992,” NBER Working Paper 6923, NBER.

Hanson, Gordon H., 2001, "Should Countries Promote Foreign Direct Investment?" NBER Working Paper, NBER.

Howenstine, Ned G. and William J. Zeile, 1994, "Characteristics of Foreign-Owned U.S. Manufacturing Establishments," Survey of Current Business, Vol. 74, No. 1 pp. 34-59.

Katz, Lawrence F. and Lawrence H. Summers. "Industry Rents: Evidence and Implications," Brookings Papers on Economic Activity (1989): 209-75.

Krueger, Alan B. and Lawrence H. Summers, "Efficiency Wages and the InterIndustry Wage Structure.” Econometrica, 56 (March 1988): 259-293.

Krueger, Alan B. and Lawrence H. Summers, 1987, "Reflections on the InterIndustry Wage Structure," in Kevin Lang and Jonathan S. Leonard, editors. Unemployment and the Structure of Labor Markets. New York: Basil Blackwell, 1987, pp. 17-47.

Lipsey, Robert E. and Fredrik Sjöholm, 2001, "Foreign Direct Investment and Wages in Indonesian Manufacturing," NBER Working Paper 8299, NBER.

Lipsey, Robert E., 2001, "Foreign Direct Investment and the Operations of Multinational Firms: Concepts, History, and Data," NBER Working Paper 8665, NBER.

Moulton, Brent R., 1986, "Random Group Effects and the Precision of Regression Estimates," Journal of Econometrics 32, 385-397. 
Table 1. The Inward FDI and Local Wage Changes

\begin{tabular}{|c|c|c|c|}
\hline \multirow{2}{*}{} & \multicolumn{2}{|c|}{$\begin{array}{c}\text { Greenfield Foreign } \\
\text { Investment }\end{array}$} & \multirow{2}{*}{$\begin{array}{c}\text { Merger and } \\
\text { Acquisition }\end{array}$} \\
\cline { 2 - 3 } & $\begin{array}{c}\text { Skill } \\
\text { Intensive }\end{array}$ & $\begin{array}{c}\text { Same Skill } \\
\text { Intensive* }\end{array}$ & \\
\hline Skilled Workers Wage & Increase & Increase & $?$ \\
\hline $\begin{array}{c}\text { Less Skilled Workers } \\
\text { Wage }\end{array}$ & $\begin{array}{c}\text { No } \\
\text { change }\end{array}$ & Increase & $?$ \\
\hline
\end{tabular}

Note: * Foreign Establishment use the same skill intensity as the local firms use. 
Table 2. Number and Employment of Foreign-Owned Establishments by Industry

\begin{tabular}{|c|c|c|c|c|c|}
\hline \multirow[b]{2}{*}{ Industry } & \multicolumn{3}{|c|}{ Foreign-owned establishments } & \multicolumn{2}{|c|}{$\begin{array}{c}\text { Foreign-owned establishments as } \\
\text { a } \% \text { of all U.S. establishments }\end{array}$} \\
\hline & $\begin{array}{l}\text { SIC } \\
\text { code }\end{array}$ & $\begin{array}{c}\text { Number of } \\
\text { establishments }\end{array}$ & $\begin{array}{l}\text { Number of } \\
\text { employees }\end{array}$ & $\begin{array}{c}\text { Number of } \\
\text { establishments }\end{array}$ & $\begin{array}{l}\text { Number of } \\
\text { employees }\end{array}$ \\
\hline Manufacturing* & & 12781 & 2004947 & 3.3 & 11 \\
\hline Food and Kindred Products & 20 & 1013 & 156123 & 4.9 & 10.4 \\
\hline Textile mill products & 22 & 203 & 48454 & 3.4 & 7.9 \\
\hline Apparel and other textile products & 23 & 116 & 26776 & 0.5 & 2.7 \\
\hline Lumber and wood products & 24 & 152 & 13492 & 0.4 & 2.1 \\
\hline Furniture and fixtures & 25 & 108 & $10000-24999$ & 0.9 & - \\
\hline Paper and allied products & 26 & 289 & 46529 & 4.5 & 7.4 \\
\hline Printing and publishing & 27 & 836 & 98209 & 1.3 & 6.6 \\
\hline Chemicals and allied products & 28 & 1635 & 240829 & 13.6 & 28.4 \\
\hline Petroleum and coal products & 29 & 360 & 27097 & 16.9 & 23.7 \\
\hline Rubber and miscellaneous plastics products & 30 & 742 & 125724 & 4.7 & 13.9 \\
\hline Leather and leather products & 31 & 27 & 5351 & 1.3 & 5.3 \\
\hline Stone, clay, and glass products & 32 & 1484 & 92791 & 9.1 & 19.8 \\
\hline Primary metal industries & 33 & 413 & 113770 & 6.4 & 17.2 \\
\hline Fabricated metal products & 34 & 686 & 101681 & 1.9 & 7.5 \\
\hline Industrial machinery and equipments & 35 & 1094 & 190106 & 2 & 10.9 \\
\hline Electronic and other electrical equipment & 36 & 812 & 224855 & 4.8 & 15.6 \\
\hline Transportation equipment & 37 & 331 & 115177 & 2.9 & 7 \\
\hline Instruments and related products & 38 & 481 & 106667 & 4.2 & 11.8 \\
\hline Miscellaneous manufacturing industries & 39 & 162 & 27570 & 1 & 7.5 \\
\hline
\end{tabular}

Notes: Data source: from Bureau of Economic Analysis Foreign Direct Investment in the United States

Establishment Data for 1992.

*: Except Tobacco products industry 
Table 3. Number and Employment of Foreign-Owned Establishments by State

\begin{tabular}{|c|c|c|c|c|c|c|}
\hline & \multicolumn{2}{|c|}{$\begin{array}{l}\text { Foreign-owned } \\
\text { establishments }\end{array}$} & \multicolumn{4}{|c|}{$\begin{array}{l}\text { Foreign-owned establishments as a \% of all U.S. } \\
\text { establishments }\end{array}$} \\
\hline & $\begin{array}{l}\text { Number of } \\
\text { establishments }\end{array}$ & $\begin{array}{l}\text { Number of } \\
\text { employees }\end{array}$ & $\begin{array}{c}\text { Number of } \\
\text { establishments }\end{array}$ & $\begin{array}{l}\text { Number of } \\
\text { employees }\end{array}$ & Value added & $\begin{array}{c}\text { Value of } \\
\text { Shipments }\end{array}$ \\
\hline All Manufacturing & 12,781 & $2,004,947$ & 3.3 & 11 & 13.7 & 14.5 \\
\hline Alabama & 218 & 38,722 & 3.4 & 10.2 & 15.4 & 15.2 \\
\hline Alaska & 18 & 2,300 & 3.6 & 14.7 & 13.5 & 14.3 \\
\hline Arizona & 116 & 10,151 & 2.4 & 5.7 & 5.5 & 6.6 \\
\hline Arkansas & 115 & 18,878 & 2.9 & 8.3 & 12 & 12.1 \\
\hline California & 1,475 & 189,710 & 2.9 & 9.7 & 11.7 & 12.8 \\
\hline Colorado & 115 & 12,715 & 2.2 & 7 & 8.4 & 9.1 \\
\hline Connecticut & 222 & 35,878 & 3.5 & 11.2 & 11.6 & 11.7 \\
\hline Delaware & 73 & 29,892 & 9.9 & 44.8 & 34 & 30.1 \\
\hline District of Columbia & 20 & 288 & 4.4 & 2.2 & 1.5 & 2 \\
\hline Florida & 495 & 43,805 & 3 & 9.3 & 10.9 & 12.5 \\
\hline Georgia & 531 & 68,415 & 5.4 & 12.3 & 19.6 & 16.4 \\
\hline Hawaii & 27 & 1,644 & 2.6 & 8 & 9.7 & 23.4 \\
\hline Idaho & 25 & 2,424 & 1.4 & 3.7 & 6.3 & 5.1 \\
\hline Illinois & 713 & 120,917 & 3.8 & 12.5 & 13.4 & 17.1 \\
\hline Indiana & 385 & 81,572 & 4.1 & 13.2 & 15.9 & 16.7 \\
\hline Iowa & 109 & 20,170 & 2.8 & 8.9 & 9.8 & 8.7 \\
\hline Kansas & 99 & 13,019 & 2.9 & 6.9 & 8.4 & 8.2 \\
\hline Kentucky & 242 & 46,294 & 5.6 & 16.8 & 17.2 & 20.1 \\
\hline Louisiana & 132 & 19,862 & 3.3 & 11.1 & 21.5 & 28.5 \\
\hline Maine & 59 & 5,995 & 2.7 & 6.6 & 8.3 & 9.3 \\
\hline Maryland & 188 & 24,615 & 4.3 & 12.7 & 14.2 & 14.8 \\
\hline Massachusetts & 351 & 48,284 & 3.5 & 10.1 & 11.7 & 13.4 \\
\hline Michigan & 443 & 74,639 & 2.7 & 8.1 & 8.7 & 10 \\
\hline Minnesota & 189 & 30,895 & 2.4 & 7.9 & 7.9 & 7.7 \\
\hline Mississippi & 109 & 13,724 & 2.9 & 5.8 & 8.7 & 8.8 \\
\hline Missouri & 273 & 34,547 & 3.5 & 8.4 & 12.3 & 10.9 \\
\hline Montana & 16 & 1,137 & 1.2 & 5.3 & 10.2 & 16.5 \\
\hline Nebraska & 62 & 9,511 & 3.1 & 9.5 & 14.7 & 9.7 \\
\hline Nevada & 36 & 2,544 & 2.9 & 9.3 & 12.6 & 12.9 \\
\hline New Hampshire & 91 & 11,807 & 3.9 & 12.6 & 13.2 & 14.5 \\
\hline New Jersey & 588 & 99,779 & 4.4 & 17.4 & 25.9 & 23.2 \\
\hline New Mexico & 33 & 3,140 & 2.1 & 8 & 5.2 & 4.5 \\
\hline New York & 620 & 94,378 & 2.3 & 9 & 10.3 & 10.9 \\
\hline North Carolina & 549 & 114,330 & 4.6 & 13.8 & 20 & 19.4 \\
\hline North Dakota & 13 & 1,181 & 1.9 & 6.4 & 6.8 & 6.4 \\
\hline Ohio & 685 & 122,716 & 3.7 & 11.7 & 15 & 16.3 \\
\hline
\end{tabular}




\begin{tabular}{lcccccc}
\hline Oklahoma & 109 & 16,494 & 2.7 & 10.6 & 12.5 & 15.2 \\
Oregon & 137 & 18,542 & 2 & 8.8 & 8.4 & 11.3 \\
Pennsylvania & 684 & 118,187 & 3.8 & 12.4 & 13.6 & 14.1 \\
Rhode Island & 42 & 6,090 & 1.6 & 6.9 & 8.6 & 10.4 \\
South Carolina & 287 & 64,229 & 5.9 & 17.5 & 20.3 & 22.1 \\
South Dakota & 17 & 2,621 & 1.9 & 7.4 & 7.3 & 6.3 \\
Tennessee & 305 & 75,880 & 4 & 15.2 & 18.3 & 22.3 \\
Texas & 858 & 105,159 & 4 & 11 & 15.4 & 15.6 \\
Utah & 47 & 6,385 & 1.9 & 6.2 & 8.5 & 9.4 \\
Vermont & 31 & 3,977 & 2.3 & 8.9 & 7.1 & 9.6 \\
Virginia & 255 & 50,031 & 3.9 & 12.3 & 13.9 & 14.5 \\
Washington & 227 & 25,119 & 2.7 & 7.4 & 8.1 & 8.7 \\
West Virginia & 69 & 16,988 & 3.9 & 21.6 & 34.3 & 35.5 \\
Wisconsin & 268 & 45,137 & 2.7 & 8.3 & 9.5 & 9.5 \\
Wyoming & 10 & 230 & 1.7 & 2.6 & 3.6 & 2.9 \\
\hline Notes: Data & source: from & Bureau & of Economic Analysis & Foreign & Direct Investment in the United States \\
Establishment Data for 1992. & & & & &
\end{tabular}


Table 4. Sample Statistics for the First Regression Strategy

\begin{tabular}{lcc}
\hline Variable & Mean & Std. Dev. \\
\hline ln(wage) & 1.034 & 0.225 \\
Individual Characteristics & & \\
Schooling (years) & 13.273 & 2.781 \\
Labor Force Experience & 19.772 & 12.048 \\
Experience Squared & 536.081 & 566.356 \\
Union Member (1=yes) & 0.204 & 0.403 \\
Lives in South (1=yes) & 0.300 & 0.458 \\
Employed Part-Time (1=yes) & 0.061 & 0.240 \\
Engineer-Scientist (1=yes) & 0.059 & 0.236 \\
White-Collar (1=yes) & 0.309 & 0.462 \\
Skilled (1=yes) & 0.190 & 0.393 \\
Semi-Skilled (1=yes) & 0.357 & 0.479 \\
Unskilled (1=yes) & 0.071 & 0.256 \\
Male (1=yes) & 0.660 & 0.474 \\
Non-White (1=yes) & 0.133 & 0.340 \\
Unmarried (1=yes) & 0.349 & 0.477 \\
Veteran (1=yes) & 0.171 & 0.376 \\
Lives in SMSA (1 =yes) & 0.710 & 0.454 \\
& & \\
Presence of Foreign Firms* & 5.359 & 8.090 \\
\hline Nit Stics &
\end{tabular}

Notes: Statistics are for 94,994 individual observations.

* Presence of foreign firms are industry (63 manufacturing industries)-state (50, D.C. merged with Maryland) level observations. 
Table 5. OLS Estimation with Industry-State Level of FDI Dependent Variable: Log of Hourly Wages

\begin{tabular}{|c|c|c|}
\hline Independent Variable & Estimated Coefficient & $t$-Statistic \\
\hline \multicolumn{3}{|l|}{ Individual Characteristics } \\
\hline Union Member & 0.055 & 11.930 \\
\hline Schooling & 0.025 & 56.813 \\
\hline Labor Force Experience & 0.011 & 43.293 \\
\hline Experience Squared & -0.0002 & -33.973 \\
\hline Lives in South & -0.032 & -7.943 \\
\hline Employed Part-Time & -0.099 & -22.381 \\
\hline Engineer-Scientist & 0.107 & 43.293 \\
\hline White-Collar & 0.010 & 1.459 \\
\hline Skilled & -0.051 & -7.538 \\
\hline Semi-Skilled & -.114 & -16.425 \\
\hline Unskilled & -0.140 & -20.075 \\
\hline Male & 0.109 & 51.793 \\
\hline Non-White & -0.039 & -11.980 \\
\hline Unmarried & -0.030 & -23.329 \\
\hline Veteran & 0.003 & 1.533 \\
\hline Lives in SMSA & 0.049 & 15.591 \\
\hline \multicolumn{3}{|l|}{ Group Characteristics } \\
\hline Presence of Foreign Firms & 0.002 & 7.425 \\
\hline Number of Obs & 94717 & \\
\hline$F$-Statistic & 1213 & \\
\hline R-Square & 0.487 & \\
\hline
\end{tabular}

Notes: Data source: Current Population Survey Merged Outgoing Rotation Groups from 1991 to 1993. Presence of foreign firms was industry-state level fraction of foreign firms. 3150 cells (50 states 63 manufacturing industries). Data are from Bureau of Economic Analysis Foreign Direct Investment in the United States Establishment Data for 1992. 


\section{Table 6. OLS Regression Estimates Dependent Variable: Log of Hourly Wages}

\begin{tabular}{|c|c|c|c|c|}
\hline Independent Variable & $(1)$ & (2) & (3) & (4) \\
\hline Presence of Foreign Firms & $\begin{array}{c}0.0020 \\
(7.4250)\end{array}$ & $\begin{array}{c}0.0004 \\
(2.0740)\end{array}$ & $\begin{array}{c}0.0015 \\
(6.9780)\end{array}$ & $\begin{array}{c}0.0001 \\
(0.5270)\end{array}$ \\
\hline Industry dummies & No & Yes & No & Yes \\
\hline State dummies & No & No & Yes & Yes \\
\hline
\end{tabular}


Table 7. Effects of Inward FDI Activity on Industry Wage Differentials (Dependent Variable=Estimated Industry Wage Differentials)

\begin{tabular}{lcccc}
\hline Independent Variable & $(1)$ & $(2)$ & $(3)$ & $(4)$ \\
\hline All Workers & & & & \\
Foreign firm's employment share & -0.079 & & -0.099 & \\
& $(-1.539)$ & & $(-2.010)$ & -0.130 \\
Foreign firm's shipment share & & -0.117 & & $(-2.863)$ \\
& & $(-2.504)$ & & 0.95
\end{tabular}

\section{Workers with 0-12 Years of Schooling}

Foreign firm's employment share $\quad-0.005$

$-0.025$

$(-0.084)$

$(-0.405)$

Foreign firm's shipment share

$-0.053$

$-0.061$

$(-0.916)$

$(-1.082)$

R-Squared

0.94

0.94

0.93

0.93

\section{Workers with 13+ Years of Schooling}

$\begin{array}{lcccc}\text { Foreign firm's employment share } & \begin{array}{c}-0.197 \\ (-2.077)\end{array} & -0.206 & \\ & & -0.212 & & -0.221 \\ \text { Foreign firm's shipment share } & & (-2.431) & & (-2.606) \\ & & 0.85 & 0.85 & 0.85\end{array}$

\section{Union Members}

Foreign firm's employment share

Foreign firm's shipment share

R-Squared
0.031

$\begin{array}{ccc} & 0.030 & \\ & (0.329) & \\ 0.018 & & 0.018 \\ (0.205) & & (0.211) \\ 0.91 & 0.91 & 0.91\end{array}$

Notes: All regressions include industry and years dummies. Weights are equal to the inverse of the variance of the estimated wage differential in the first regression. Regressions for (1) and (2) include other control variables of industry characteristics: union membership, capital-labor ratio, average-establishment size, and profit. $t$-statistics are in parenthesis. Number of observations are 378 for all specifications and panels. 
Table 8. Effects of Foreign Firms Presence on Industry Wage Differentials (Dependent Variable=Estimated Industry Wage Differentials)

\begin{tabular}{|c|c|c|c|c|}
\hline Independent Variable & $\begin{array}{c}\text { All Workers } \\
\text { (1) }\end{array}$ & $\begin{array}{c}\text { Workers with } \\
0-12 \text { Years of } \\
\text { Schooling } \\
(2)\end{array}$ & $\begin{array}{c}\text { Workers with } \\
13+\text { Years of } \\
\text { Schooling } \\
\text { (3) }\end{array}$ & $\begin{array}{c}\text { Union } \\
\text { Members } \\
(4) \\
\end{array}$ \\
\hline $\begin{array}{l}\text { Proportion of number of } \\
\text { Foreign-owned establishment }\end{array}$ & $\begin{array}{c}0.002 \\
(0.093)\end{array}$ & $\begin{array}{c}0.001 \\
(0.671)\end{array}$ & $\begin{array}{c}0.002 \\
(0.536)\end{array}$ & $\begin{array}{c}0.003 \\
(0.909)\end{array}$ \\
\hline Number of Obs. & 126 & 126 & 126 & 126 \\
\hline R-Squared & 0.97 & 0.97 & 0.90 & 0.94 \\
\hline
\end{tabular}

Notes: All regressions include year dummies. Weights are equal to the inverse of the variance of the estimated wage differential in the first regression. $t$-statistics are in parenthesis. 